\title{
PELAKSANAAN JAMINAN SOSIAL BAGI MASYARAKAT BAGI BADAN PENYELENGGARAAN JAMINAN SOSIAL (BPJS) (STUDI DI KANTOR BPJS KOTA TANJUNG BALAI)
}

\author{
Herlina Panjaitan 1), Rahmat ${ }^{2)}$ \\ ${ }^{1)}$ Fakultas Hukum Universitas Asahan \\ ${ }^{2)}$ Fakultas Hukum Universitas Asahan \\ email: ${ }^{1}$ rahmathidayah2585@gmail.com ${ }^{2)}$
}

\begin{abstract}
ABSTRAK
Jaminan sosial merupakan hak konstitusional setiap warga negara yang dijamin dengan undang-undang dan ditegakkan untuk memberikan pelayanan yang maksimal. Jaminan kesehatan adalah jaminan berupa keselamatan kesehatan agar anggota memperoleh manfaat pelayanan kesehatan dan perlindungan dalam bentuk keinginan kesehatan mendasar yang menyenangkan yang diberikan kepada setiap orang yang telah membayar tunai atau yang iurannya dibayarkan kepada Pemerintah. Melalui pemberian rencana asuransi kesehatan maka masyarakat akan diberikan kepastian hukum atas kesehatan yang perlu diperoleh melalui masyarakat. BPJS ditugaskan kepada pihak yang berwenang untuk menyelenggarakan program jaminan pemeliharaan kesehatan bagi seluruh rakyat Indonesia, khususnya untuk kepentingan Pegawai Negeri Sipil, Penerima Pensiun PNS dan TNI / POLRI, Veteran, Perintis Kemerdekaan beserta keluarganya dan berbagai badan usaha atau orang pribadi. BPJS sebagai penerbit asuransi kesehatan perlu berada pada posisi untuk memastikan bahwa setiap anggota masyarakat memperoleh layanan kesehatan yang maksimal.
\end{abstract}

Kata kunci: Jaminan, Sosial, BPJS, Tanjungbalai.

\section{ABSTRACT}

Social security is a constitutional right of every citizen guaranteed by law and enforced to provide maximum service. Health insurance is a guarantee in the form of health safety so that members receive health service benefits and protection in the form of a pleasant basic health wish that is given to everyone who has paid cash or whose contributions are paid to the Government. By providing a health insurance plan, the public will be given legal certainty for health that needs to be obtained through the community. BPJS is assigned to the authorities to administer health care insurance programs for all Indonesians, especially for the benefit of Civil Servants, Retired Recipients for PNS and TNI I POLRI, Veterans, Perintis Kemerdekaan and their families and various business entities or individuals. BPJS as the issuer of health insurance needs to be in a position to ensure that every member of the community gets maximum health services.

Keywords: Social Security, BPJS, Tanjungbalai. 


\section{PENDAHULUAN}

Jaminan sosial merupakan hak konstitusional setiap warga negara yang dijamin dengan undang-undang dan ditegakkan untuk memberikan pelayanan yang maksimal. Jaminan kesehatan adalah jaminan berupa keselamatan kesehatan agar anggota memperoleh manfaat pelayanan kesehatan dan perlindungan dalam bentuk keinginan kesehatan mendasar yang menyenangkan yang diberikan kepada setiap orang yang telah membayar tunai atau yang iurannya dibayarkan kepada Pemerintah ${ }^{1}$. Melalui pemberian rencana asuransi kesehatan maka masyarakat akan diberikan kepastian hukum atas kesehatan yang perlu diperoleh melalui masyarakat.

BPJS ditugaskan kepada pihak yang berwenang untuk menyelenggarakan program jaminan pemeliharaan kesehatan bagi seluruh rakyat Indonesia, khususnya untuk kepentingan Pegawai Negeri Sipil, Penerima Pensiun PNS dan TNI / POLRI, Veteran, Perintis Kemerdekaan beserta keluarganya dan berbagai badan usaha atau orang pribadi. $^{2}$ BPJS sebagai penerbit asuransi kesehatan perlu berada pada posisi untuk memastikan bahwa setiap anggota masyarakat

1 Pasal 1 Angka 1, Peraturan Pemerintah Republik Indonesia Nomor 101 Tahun 2012, Tentang Penerima Bantuan Dana Jaminan Kesehatan., n.d.

2 Agung Suharyanto Ade Irma Suryani, "Implementasi Kebijakan Badan Penyelenggara Jaminan Kesehatan (BPJS) Didalam Meningkatkan Layanan Administrasi Kesehatan Di Rumah Sakit Umum Silabuhuan Kabupaten Padang Lawas," Jurnal Administrasi Publik, n.d. helm, 87 . memperoleh layanan kesehatan yang maksimal.

Penyelenggaraan perlindungan sosial merupakan tanggung jawab bangsa yang diamanatkan dengan bantuan UUD 1945. Terbitnya Undang-Undang tentang Badan Penyelenggara Jaminan Sosial sebagai pelaksana Undang-Undang Sistem Jaminan Sosial Nasional merupakan wujud akuntabilitas negara dalam menjamin kesejahteraan rakyatnya. Melalui mekanisme BPJS ini diharapkan keinginan masyarakat Indonesia akan kesehatan dapat terjamin, sehingga banyak kasus pengabaian penderita yang sebelumnya tidak mempunyai uang untuk berobat dapat teratasi dan tidak muncul lagi di masa mendatang. Keterbatasan ekonomi dimana masyarakat kota Tanjungbalai yang berpenghasilan dari nelayan dengan memenuhi kehidupan sehari-hari sudah berkecukupan. Banyak masyarakat yang belum berusia dewasa yang tinggal didaerah pesisir yang mengalami suatu putus sekolah dikarenakan keterbatasan ekonomi yang dimiliki oleh keluarga. Mencari makan sehari-hari saja mereka merasa cukup namun bila dikenakan pembebanan untuk dikenakan suatu tagihan iuran dalam memenuhi suatu kewajiban membayar BPJS kesehatan tentu merasa keberatan. "Badan Penyelenggara Jaminan Sosial, yang merupakan badan penyelenggara yang berbentuk badan hukum Publik untuk memberikan perlindungan terhadap pekerja Indonesia. Undang-undang tersebut menyebutkan bahwa pekerja berhak memperoleh perlindungan dan jaminan kesehatan yang 
diselenggarakan oleh BPJS Kesehatan". ${ }^{3}$

Walaupun kesehatan merupakan suatu kebutuhan primer bagi kehidupan manusia. Namun dengan keterbatasan suatu penghasilan membuat masyarakat untuk melupakan sejenak untuk tertib membayar administrasi kesehatan. Tujuan dari badan penyelenggara kesehatan merupakan tujuan perlindungan kesehatan yang bersifat secara positif namun ini dipandang oleh sebagian kalangan masyarakat merupakan suatu beban.

Keterbatasan pendidikan yang dimiliki oleh masyarakat kota Tanjungbalai khususnya yang berada di suatu daerah pesisir memprihatinkan, dimana dengan keterbatasan pendidikan sulit bagi BPJS Kota Tanjungbalai untuk menyelenggarakan jaminan kesehatan. Masyarakat daerah pesisir hampir rata-rata tidak memiliki suatu kelengkapan administrasi kependudukan seperti KTP maupun Kartu Keluarga. Sehingga hal ini dalam melakukan pengurusan BPJS mengalami suatu hambatan karena tidak terpenuhinya kelengkapan administrasi kependudukan. Masyarakat yang belum lengkap administrasi kependudukannya mengalami suatu kendala. Pihak BPJS kesehatan menyarankan untuk melakukan pelengkapan administrasi data kependudukan. Disisi lain masyarakat mengalami suatu kendala dalam melakukan suatu pengurusan

\footnotetext{
3 Mangaraja Manurung Indra Perdana, "Tinjauan Yuridis Tentang Perlindungan Pekerja Migran Ditinjau Dari UU No. 17 Tahun 2017 Tentang Perlindungan Pekerja Migran Indonesia," Jurnal Pionir Vol 6, No (2020): 1-7.
}

data kependudukan karena kurangya pengetahuan dalam melakukan pengurusan jaminan kesehatan. Masyarakat yang tersangkut dalam pengurusan jaminan kesehatan merasa menyerah untuk tidak melakukan pengurusan BPJS karena keterbatasan kelengkapan data maupun pengetahuan yang dimiliki. "Pelayanan publik diartikan sebagai Kegiatan atau rangkaian kegiatan dalam rangka pemenuhan kebutuhan pelayanan sesuai dengan peraturan perundang-undangan bagi setiap warga Negara dan penduduk atas barang dan jasa, atau pelayanan administratif yang disediakan oleh penyelenggara pelayanan publik.(pasal 1 ayat(1) UU No.25 Tahun 2009) maka berdasarkan ketentuan undang-undang ini yang dimaksud dengan pelayan publik adalah setiap institusi penyelenggara Negara, korporasi, lembaga independen yang dibentuk berdasarkan undang-undang untuk kegiatan pelayanan publik dan badan hukum lain yang dibentuk sematamata untuk kegiatan pelayanan public". ${ }^{4}$

Berdasarkan hal tersebut maka perlu bagi pemerintah daerah untuk melakukan suatu pengkajian untuk memikirkan solusi mengatasi permasalahan-permasalahan yang dihadapi oleh masyarakat. Masyarakat perlu dilakukan pembantuan untuk mendapatkan suatu jaminan kesehatan. Pihak badan penyelenggara kesehatan perlu melakukan suatu ordinasi kepada

4 Seminar Nasional Multidisiplin Ilmu 2017 and Junindra Martua, "Peran Birokrasi Pemerintah Sebagai Penyelenggara Pelayanan Publik," 2017, https://doi.org/10.31227/osf.io/5xvew. 


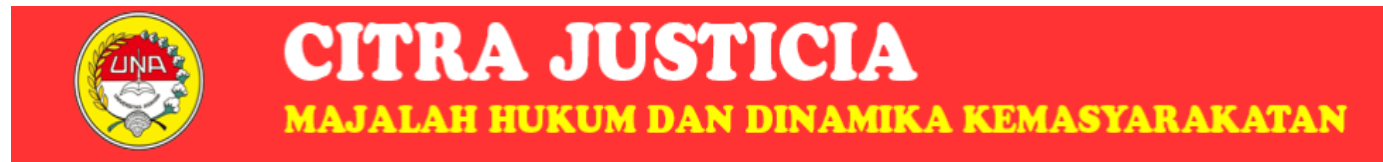

\section{Volume 22 No. 1, FEBRUARI 2021 ISSN 2686-5750 (ONLINE) \\ ISSN 1411-0717 (CETAK)}

pemerintah daerah terkait masih banyaknya masyarakat Kota Tanjungbalai yang masih belum mendapatkan suatu jaminan kesehatan. Hingga perlu dilakukan grafik maupun data jumlah masyarakat kota Tanjungbalai dengan jumlah kartu jaminan kesehatan yang dikeluarkan. Pemerintah harus mampu mendorong masyarakat melalui perangkat daerahnya untuk segera melakukan pengurusan suatu jaminan kesehatan. Bila hal ini dibiarkan maka cita-cita nasional untuk mensejahterakan rakyat akan tidak tercapai. Karena masyarakat yang sejahtera dalam masyarakat yang sehat. Masyarakat yang sehat akan mampu meningkatkan pertumbuhan ekonomi dan mendorong kemajuan suatu roda perekonomian pemerintah daerah maupun pemerintah pusat. Ekonomi yang meningkat akan mencerdaskan kehidupan bangsa dengan konsumsi makanan dan kesehatan yang bergizi bagi masyarakat Kota Tanjungbalai. Hal ini merupakan suatu bagian dari pemberian jaminan kesehatan.

Kurangnya fasilitas kesehatan yang ada dirumah sakit umum Kota Tanjungbalai sehingga membuat tidak kondusifnya penanganan suatu pasien dalam mengalami suatu permasalahan kesehatan. Kurangnya ketersedian ruangan kamar opname bagi pasien membuat program jaminan kesehatan tidak terselenggara secara maksimal. Program badan penyelenggara kesehatan bukan hanya diukur dari segi penerbitan ataupun pembayaran iuran BPJS namun implementasi dari program jaminan kesehatan. Jaminan kesehatan itu harus mampu menjamin setiap warga negara Indonesia secara khusus mendapatkan suatu pelayanan kesehatan. Sehingga bila penyelenggaraan pemberian jaminan kesehatan tidak berjalan dengan baik yang tujuannya memberikan suatu penyembuhan atau pemulihan hal ini hanya sebatas semboyan saja.

Sebelum adanya BPSJ masih banyak manusia yang belum mendapatkan sesuatu yang terjamin secara adil dan merata. Terlebih non PNS selalu dikecualikan untuk mendapatkan pelayanan kesehatan dibandingkan dengan PNS. Angka hitungan ini menimbulkan masalah di antara lingkungan sekitar yang melibatkan asuransi kesehatan. Waktu berlalu dan pembenahan generasi BPSJ hadir untuk mengatasi segala permasalahan kesehatan. Dengan menawarkan pelayanan kesehatan untuk semua orang selain pengecualian. Pelimpahan tanggung jawab untuk menanggung beban risiko tersebut, kepada berbagai kejadian yang berada dalam posisi untuk mengambil alih tanggung jawab. $^{5}$

Badan Penyelenggara Jaminan Sosial, BPJS Kesehatan adalah badan hukum hukum publik yang bertanggung jawab kepada Presiden dan memiliki fitur untuk menyelenggarakan polis asuransi kesehatan. Dalam Pasal 246 Kitab Undang-Undang Hukum Dagang Indonesia (KUHD), asuransi atau asuransi adalah suatu perjanjian, di mana penanggung mengikatkan diri pada tertanggung, dengan bantuan menerima premi, untuk mengkompensasinya atas kehilangan, kerusakan, atau kehilangan keuntungan yang diharapkan, yang

5 Sri Rejeki Hartono, Hukum Asuransi Dan Perusahaan Asuransi., ed. Sinar Grafika (Jakarta, 2008). hlm, 12. 
mungkin harus dilalui karena peristiwa yang tidak terbatas. Asuransi atau pertanggungan (Verzekering), yang mengandung arti adanya peluang yang tidak dapat dipastikan, dan terdapat pelimpahan tanggung jawab untuk menanggung beban risiko tersebut, kepada berbagai kejadian yang berada dalam posisi untuk mengambil alih tanggung jawab. ${ }^{6}$

BPJS sebagai perlindungan asuransi yang diberikan kepada negara kepada setiap warga negara yang memberikan perlindungan kesehatan kepada negara. Negara ingin memberikan jaminan kesehatan kecuali untuk setiap warga negara kecuali membedakan semua jenis lingkaran publik dan pribadi. Bahkan pihak berwenang berkewajiban memastikan bahwa setiap warga lingkungan dari Sabang hingga Marauke telah mendapatkan layanan kesehatan dan asuransi nasional. Penyelenggaraan kesehatan yang dilakukan oleh badan penyelenggara kesehatan mengalami suatu kendala, banyak masyarakat yang tidak secara menyeluruh untuk didapatkan suatu jaminan kesehatan. Karena masyarakat sebagian tersebut teridiri dari masyarakat kebanyakan yang berada dan tinggal yang mencari suatu nafkah didaerah pesisir. Hal ini menjadi suatu problema. Perlunya dilakukan suatu penanggulangan bagi setiap lapisan masyarakat daerah pesisir untuk mendapatkan suatu perlindungan dengan jaminan kesehatan. Pemerintah daerah perlu mendiskusikan ini dan segera membuat program kebijakan dalam menumbuhkan ekonomi masyarakat

${ }^{6}$ Ibid. agar kewajiban dalam memenuhi pembayaran iuran BPJS kesehatan dapat terlaksana.

"Kewajiban BPJS yang telah diatur oleh Undang-Undangbahwa BPJS menentukan dan melaksanakan tugasnya, Memberikan nomor identitas tunggal kepada Peserta, yang dimaksud dengan "nomor identitas tunggal" adalah nomor yang diberikan secara khusus dari BPJS agar peserta dapat tertib dalam administrasi sehingga pendataan dapat akurat kemudian dapat memberikan jaminan kepada peserta dari nomor idenitas tunggal yang diberikan identitas tersebut berlaku untuk semua program jaminan social". 7

Rendahnya kualitas pelayanan publik merupakan salah satu sorotan yang diarahkan pada bentuk pemerintah dalam menawarkan pelayanan kepada publik. Peningkatan penawaran publik dalam reformasi teknologi adalah harapan semua orang, tetapi tunggangan itu tidak lagi memiliki keterampilan raksasa perubahan. Berbagai respon masyarakat ternyata cenderung menunjukkan bahwa cukup banyak jenis pelayanan publik yang mengalami kemunduran yang antara lain ditandai dengan banyaknya penyimpangan dalam pelayanan publik yang lamban dalam memberikan pelayanan serta merupakan salah satu komponen dari penawaran umum yang ada. disorot secara luas.

Berdasarkan disiplin pelayanan publik, telah dilakukan upaya untuk

7 Zaid Afif Rini Liana, Emmi Rahmiwita, "Jurnal Pionir LPPM Universitas Asahan Vol. 5 N0.4 Juli-Desember 2019” 5, no. 24 (2019): 343-48. 
menetapkan kebutuhan pelayanan publik dalam mewujudkan standar penyelenggara publik yang cepat, murah, dan transparan. Hal ini terkait dengan pelaksanaan struktur dan pendekatan pelayanan yang tidak efektif, berbelit-belit, lamban, tidak membalas kepentingan, merupakan rangkaian atribut negatif yang dilimpahkan kepada birokrasi. Hal ini merupakan harga yang buruk dari sebuah penyelenggaraan pelayanan kesehatan. Tentunya hal ini terhitung tidak bisa dibenarkan dengan menggunakan wewenang sedemikian rupa sehingga berkewajiban memastikan bahwa setiap emiten penyedia kesehatan harus dimaksimalkan dalam menyelenggarakan kesehatan.

BPSJ yang menjadi sorotan dalam pembelajaran ini dalam menyelenggarakan beberapa hal perencanaan asuransi kesehatan yang ada di suatu kabupaten / kota. Berhasil tidaknya struktur rencana jaminan kesehatan dan penawaran kesehatan yang diterapkan BPJS bergantung pada standar operasional yang dimiliki dan pelaksanaan penawaran kesehatan yang dapat dilihat oleh masyarakat. Lingkungan adalah penentu dan penentu perlunya beberapa hal penyelenggaraan kesehatan yang dilakukan untuk BPJS. Karena pada prinsipnya BPJS merupakan cakupan dari wewenang pusat dimana setiap tempat harus tetap menjadi wadah yang sederajat berdasarkan kebutuhan operasional di masing-masing kabupaten / kota. Perlunya dilakukannya suatu perbaikan dan koreksi dalam hal ini yang merupakan suatu krusial yang perlu diperhatikan dan diperbaiki. Jangan sampai masyarakat hanya mengangap bahwa program BPJS hanyalah sebatas program kesehatan namun tidak menjangkau suatu kesehatan bagi masyarakat. Serta perlunya publikasi secara jelas dan memudahkan masyarakat untuk memahami program BPJS kesehatan.

Wujud akuntabilitas negara dalam menjamin kesejahteraan rakyatnya. Melalui mekanisme BPJS ini diharapkan keinginan masyarakat Indonesia akan kesehatan dapat terjamin, sehingga banyak kasus pengabaian penderita yang sebelumnya tidak mempunyai uang untuk berobat dapat teratasi dan tidak muncul lagi di masa mendatang. Sebelum adanya BPSJ masih banyak manusia yang belum mendapatkan sesuatu yang terjamin secara adil dan merata. Terlebih non PNS selalu dikecualikan untuk mendapatkan pelayanan kesehatan dibandingkan dengan PNS. Angka hitungan ini menimbulkan masalah di antara lingkungan sekitar yang melibatkan asuransi kesehatan. Waktu berlalu dan pembenahan generasi BPSJ hadir untuk mengatasi segala permasalahan kesehatan. Dengan menawarkan pelayanan kesehatan untuk semua orang selain pengecualian.

Berlandaskan penelitian diatas sehingga penulis mengangkat judul Pelaksanaan Jaminan Sosial Bagi Masyarakat Bagi Badan Penyelenggaraan Jaminan Sosial (BPJS) (Studi di Kantor BPJS Kota Tanjung Balai).

\section{METODE PENELITIAN}

Metode di dalam penelitian ini adalah mengunakan metode dengan pendekatan empiris, yaitu melighat suatu keadaan permasalahan dari fakta-fakta yang terjadi dilapangan. 
Kemudian data-data tersebut dikumpulkan sebagai bahan untuk mencawab setiap masalah yang diangkat dalam penelitian ini. Dengan mengunakan metode empiris maka capaian yang ingin dilakukan dalam menemukan suatu kebenaran ilmiah.

Jenis Penelitian Didalam menjalankan pendekatan yuridis empiris ini, Dengan menggunakan metode deduktif bisa menggambarkan ketentuan-ketentuan mengenai Pelaksanaan Jaminan Sosial Bagi Masyarakat Bagi Badan Penyelenggaraan Jaminan Sosial (BPJS) (Studi di Kantor BPJS Kota Tanjung Balai). Sedangkan metode induktif ialah data yang diperoleh dari hasil penelitian dilapangan demi diambil kesimpulan yang bersifat umum.

Lokasi penelitian dilakukan di kota Tanjungbalai, yakni pada Kantor BPJS Tanjung Balai, dipilihnya kantor BPJS Tanjung Balai ini mengingat objek penelitian yang hendak dilakukan berkenaan dengan Pelaksanaan Jaminan Sosial Bagi Masyarakat Bagi Badan Penyelenggaraan Jaminan Sosial (BPJS) (Studi di Kantor BPJS Kota Tanjung Balai), sehingga dengan demikian sungguh memudahkan peneliti demi mendapatkan informasi atau data yang berhubungan dengan Pelaksanaan Jaminan Sosial Bagi Masyarakat Bagi Badan Penyelenggaraan Jaminan Sosial (BPJS) (Studi di Kantor BPJS Kota Tanjung Balai).

Sumber Data Penulis dalam melakukan penelitian untuk mengabil data penelitian menggunakan sumber data, dimana sumber data yang digunakan di penelitian ini didapat dari sumber data primer dan sumber data sekunder. Dengan menggunakan dua macam bahan hukum yang meliputi Sumber data primer yaitu sumber data yang diperoleh secara langsung dari sumber pertama yang terkait dengan permasalahan yang akan dibahas. Sumber data yang diperoleh dari lapangan dengan wawancara berbagai pihak yang menyangkut terhadap permasalahan dalam penelitian.

Sumber data sekunder yaitu bahan hukum yang diperoleh Buku sebagai salah satu bahan hukum merupakan berbagai buku yang berkaitan dengan pembahasan penelitian yang dilakuan oleh penulis mengenai bahan hukum yang terdiri dari: a. Merupakan hasil dari bahan pustaka ataupun dari literatur buku; b. Bahan yang berasal dari berbagai hasil seminar dan tulisan artikel yang ada di internet sebagai bahan hukum yang berhubungan dengan penelitian serta pembahasan dalam penulisan skripsi ini. c. Selanjutnya mengambil dari berbagai bahan hukum dari hasil yang dilakukan penelitian sebelumnya.

Teknik pengumpul data hendak sungguh menentukan hasil penelitian sehingga apa yang menjadikan tujuan penelitian ini bisa tercapai. Demi mendapatkan hasil penelitian yang objektif dan bisa dibuktikan kebenaranya serta bisa di pertanggungjawabkan hasilnya, sehingga didalam kebenarannya serta dan dipertanggungjawabkan hasilnya, sehingga didalam penelitian ini hendak di pergunakan alat pengumpul data.

Didalam memporelah data yang diperlukan, sehingga dilakukan wawancara terhadap responden yang dilakukan secara langsung ialah 


\section{Volume 22 No. 1, FEBRUARI 2021 ISSN 2686-5750 (ONLINE) \\ ISSN 1411-0717 (CETAK)}

dengan BPJS Kota Tanjung Balai terkait Pelaksanaan Jaminan Sosial Bagi Masyarakat Bagi Badan Penyelenggaraan Jaminan Sosial (BPJS) (Studi di Kantor BPJS Kota Tanjung Balai).

Analisis data kualitatif dilakukan apabila data empiris yang diperoleh ialah data kualitatif berupa kumpulan berwujud kata-kata dan tidak rangkaian angka serta tidak bisa disusun didalam kategorikategori/struktur klasifikasi. Data bisa saja dikumpulkan didalam aneka macam cara (observasi, wawancara, intisari dokumen, pita rekaman) dan biasanya diproses terlebih dahulu sebelum siap digunakan (melalui pencatatan, pengetikan, penyuntingan, atau alih-tulis), tetapi analisis kualitatif tetap menggunakan katakata yang biasanya disusun ke didalam teks yang diperluas, dan tidak menggunakan perhitungan matematis atau statistika sebagai alat bantu analisis.

\section{HASIL DAN PEMBAHASAN Pelaksanaan Jaminan Sosial Bagi Masyarakat Bagi Badan Penyelenggaraan Jaminan Sosial (BPJS) di Kota Tanjungbalai.}

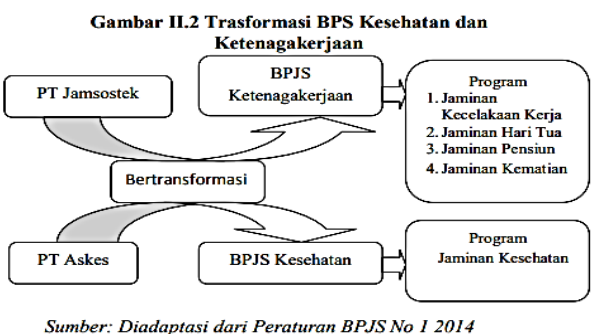

Kantor pusat BPJS Kesehatan Kota Tanjung Balai, Sumatera Utara. BPJS Kesehatan merupakan salah satu perusahaan jaminan sosial kesehatan. BPJS adalah transformasi dari PT Askes (Persero), karakteristik mendasar dari BPJS Kesehatan adalah menyediakan jaminan kesehatan bagi seluruh masyarakat Indonesia. Dalam prosesnya, BPJS Kesehatan membantu memastikan kesesuaian dengan polis asuransi kesehatan. Asuransi kesehatan BPJS dapat dicapai dengan mudah dengan kemitraan klinik raksasa selama Indonesia. Dalam rangka memandu layanannya, BPJS Kesehatan melayani baik secara langsung melalui kantor maupun online melalui situs internet BPJS Kesehatan yang dapat diakses secara online. Membuka atau mendaftarkan BPJS sebenarnya juga mudah dengan jumlah dana BPJS yang terjangkau. Berbagai keinginan terkait pelayanan BPJS kesehatan juga bisa dilakukan bpjs online sesuai dengan cek popularitas bpjs kesehatan, pembayaran bpjs, dan lain-lain. Untuk informasi tambahan lebih lanjut dapat menghubungi kontak atau call center BPJS Kesehatan.
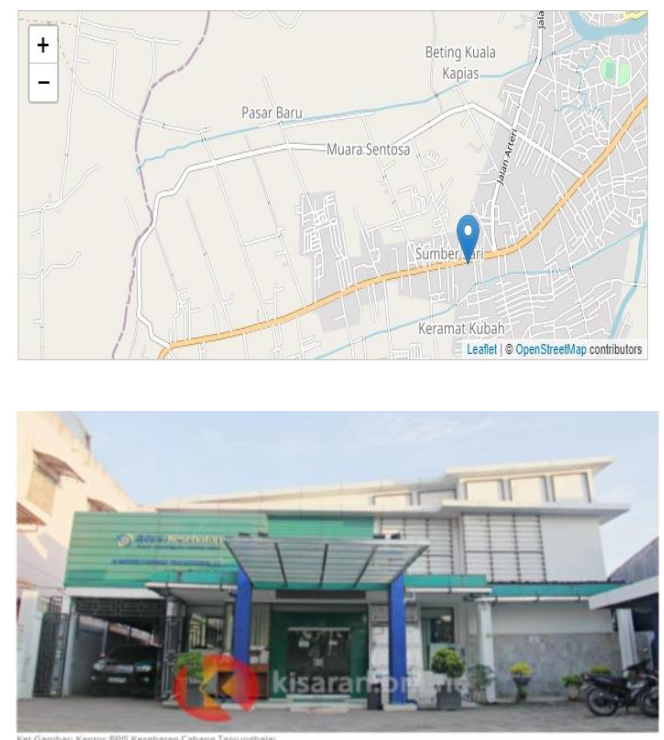

Berdasarkan hasil wawancara dengan Divisi Sumber Daya Manusia, Umum dan Komunikasi, Mohamad Syafriadi didampingi oleh Dessy Prassinta selaku Kepala Divisi 
Penjaminan Manfaat Rujukan, dan Dewi Irmayani Harahap selaku Kepala Divisi Penjaminan Manfaat Utama, diperoleh informasi:

$$
\text { Pada April 2019, BPJS }
$$

Kesehatan sudah menggelontorkan uang Rp. sebelas triliun untuk membayar BPJS Kesehatan karena klaim ke rumah sakit. Khusus di wilayah kantor departemen Tanjungbalai yang meliputi enam kabupaten, BPJS Kesehatan telah membayar klaim untuk 223 rumah sakit dengan fasilitas kesehatan tingkat pertama (FKTP) dan 36 rumah sakit di Fasilitas Kesehatan Rujukan Tingkat Lanjut (FKRTL) dengan keseluruhan biaya klaim sebesar $\mathrm{Rp}$ 57.696 . 140.221. ${ }^{8}$

Hal tersebut pernah disampaikan Kepala BPJS Kesehatan Cabang Tanjungbalai melalui Bagian Sumber Daya Manusia, Umum dan Komunikasi, Mohamad Syafriadi didampingi oleh Dessy Prassinta selaku Kepala Bidang Penjaminan Manfaat Rujukan, dan Dewi Irmayani Harahap selaku Kepala Bidang Manfaat Utama. Jaminan. ${ }^{9}$

"Sampai hari ini, klaim institusi medis yang sudah melewati verifikasi dan jatuh tempo akan dibayar dengan menggunakan BPJS Kesehatan menggunakan mekanisme first in first out. Urutan biaya disesuaikan dengan catatan kami. Fasilitas kesehatan yang sudah menyerahkan lengkap berkas pertama, jalur transaksi harga untuk

${ }^{8}$ Wawancara Dengan Bidang SDM, Umum Dan Komunikasi, Mohamad Syafriadi Didampingi Dessy Prassinta Selaku Kepala Bidang Penjaminan Manfaat Rujukan, Dan Dewi Irmayani Harahap Selaku Kepala Bidang Penjaminan Manfaat Primer., n.d.

${ }^{9}$ Ibid. klaim akan dilakukan. diproses dulu. Upaya penyelesaian biaya fasilitas kesehatan bisa terwujud karena ada dukungan penuh dari Kementerian Keuangan dan Kementerian Kesehatan, "kata Syafriadi. ${ }^{10}$

Menurut Syafriadi, setiap tanggal lima belas merupakan tanggal pembayaran kapitasi FKTP. Oleh karena itu, ada kemungkinan cicilan non kapitasi dan tagihan klinik akan dilunasi melalui BPJS Kesehatan keesokan harinya. Ini merupakan mekanisme retribusi yang rutin dilakukan setiap bulan untuk BPJS Kesehatan. ${ }^{11}$

"Biasanya rekan-rekan perbankan kami mengajukan transaksi pembayaran kapitasi ini terlebih dahulu. Namun, kami pastikan tugas harga ke fasilitas kesehatan sesuai kebijakan yang berlaku paling lambat hari ini. Kami juga telah berkoordinasi dengan semua kantor departemen, Sehingga setiap departemen tempat kerja dapat memajang dan memastikan bahwa layanan kesehatan di wilayah kerja telah dibayar sesuai dengan ketentuan yang berlaku, "ujar Syafriadi. ${ }^{12}$

Syafriadi mengatakan, dengan membayar BPJS Kesehatan karena klaim fasilitas kesehatan, diharapkan pihak pelayanan kesehatan juga dapat meningkatkan tanggung jawabnya sesuai dengan ketentuan yang diatur. Syafriadi juga berharap institusi kesehatan dapat semakin maksimal

${ }^{10}$ Ibid.
${ }^{11}$ Ibid.
${ }^{12}$ Wawancara Dengan Bidang SDM, Umum Dan Komunikasi, Mohamad Syafriadi Didampingi Dessy Prassinta Selaku Kepala Bidang Penjaminan Manfaat Rujukan, Dan Dewi Irmayani Harahap Selaku Kepala Bidang Penjaminan Manfaat Primer. 
dalam menghadirkan layanan kesehatan bagi pasien JKN-KIS. ${ }^{13}$

"Kami terus berkoordinasi dengan layanan kesehatan yang melayani anggota JKN-KIS agar dapat memberikan layanan kelas satu tanpa diskriminasi sebagaimana diatur dalam kebijakan yang ditetapkan oleh pemerintah. Dengan demikian, masyarakat diharapkan semakin yakin bahwa kebijakan ini akan terus berlanjut, rumah sakit akan lebih tenang dan kesehatan para pekerja. Rasa nyaman, "kata Syafriadi. ${ }^{14}$

$$
\text { Syafriadi }
$$

menginformasikan bahwa jaminan JKN-KIS yang dikelola BPJS Kesehatan tidak lagi hanya menawarkan layanan kesehatan yang terjamin dan terjamin, namun juga berkontribusi pada pertumbuhan industri kesehatan dan penciptaan lapangan kerja. Katanya, kalau ada kekurangan, harus sama-sama konstan. Menurutnya, tidak boleh ada diskriminasi karier yang bersifat kasuistik, kemudian digeneralisasikan, padahal peserta JKN-KIS memang banyak yang terlayani dengan baik. ${ }^{15}$

"Kedepannya Insya Allah pihak yang berwajib akan terus menjaga keberlangsungan cakupan JKN-KIS dan pelayanan kepada

${ }^{13}$ Wawancara Dengan Bidang SDM, Umum Dan Komunikasi, Mohamad Syafriadi Didampingi Dessy Prassinta Selaku Kepala Bidang Penjaminan Manfaat Rujukan, Dan Dewi Irmayani Harahap Selaku Kepala Bidang Penjaminan Manfaat Primer.

${ }^{14}$ Wawancara Dengan Bidang SDM, Umum Dan Komunikasi, Mohamad Syafriadi Didampingi Dessy Prassinta Selaku Kepala Bidang Penjaminan Manfaat Rujukan, Dan Dewi Irmayani Harahap Selaku Kepala Bidang Penjaminan Manfaat Primer.

15 Ibid. lingkungan akan terus ditingkatkan. Kami mengucapkan terima kasih kepada para vendor operator serta mohon maaf dan mengapresiasi kerjasama mereka., pemahaman dan ketekunan selama ini, "tambahnya. Syafriadi ${ }^{16}$.

$\begin{array}{lcc} & \text { Pelaksanaan Jaminan } & \text { Sosial } \\ \text { Bagi Masyarakat } & \text { Bagi } & \text { Badan } \\ \text { Penyelenggaraan Jaminan } & \text { Sosial }\end{array}$ (BPJS) di Kota Tanjungbalai. Telah sesuai dengan ketentuan hukum yang berlaku dalam memberikan suatu jaminan kesehatan. Namun perlunya dilakukan suatu peningkatan dalam menyelenggarakan suatu pelayanan publik kepada masyarakat dalam bidang kesehatan. Penyelenggaraan jaminan kesehatan tersebut adalah berdasarkan ketentuan BPJS dilaksanakan pembayara iuran dalam mendapatkan suatu jaminan kesehatan berupa kartu jaminan kesehatan.

Kartu jaminan kesehatan tersebut dibagi atas kelas-kelas dalam suatu pelayanan kesehatan. Penggolongan kategori tersebut merupakan suatu pembeda dalam mendapatkan suatu pelayanan kesehatan karena diukur dari segi nominal iuran yang akan dibayarkan dalam menyelenggarakan suatu jaminan kesehatan. Setiap masyarakat mendapatkan suatu pelayanan secara merata namun ada pembeda yang dilakukan berdasarkan ketentuan aturan BPJS dalam memberikan suatu pelayanan kesehatan bagi masyarakat. Setiap masyarakat merupakan suatu obyek dari suatu penyelenggaraan jaminan kesehatan. Melalui UU BPJS kesehatan masyarakat dapat diselamatkan tanpa biaya terlebih dahulu pada saat mengalami suatu 


\section{Volume 22 No. 1, FEBRUARI 2021 ISSN 2686-5750 (ONLINE)}

ISSN 1411-0717 (CETAK)

permasalahan kesehatan. Sebelum lahirnya UU BPJS masyarakat masyarakat mengalami suatu permasalahan dalam kesehatan yang perlunya mendapatkan suatu pertolongan yang perlu didahulukan tanpa meminta bayaran terlebih dahulu dengan program BPJS maka hal tersebut dapat diatasi.

\section{Prosedur Pelayanan BPJS}

Untuk pelayanan dirumah sakit ada dua yaitu pelayanan rawat inap dan pelayanan rawat jalan.

1). Prosedur pelayanan rawat jalan

Gambar 2.1 alur pelayanan rawat jalan

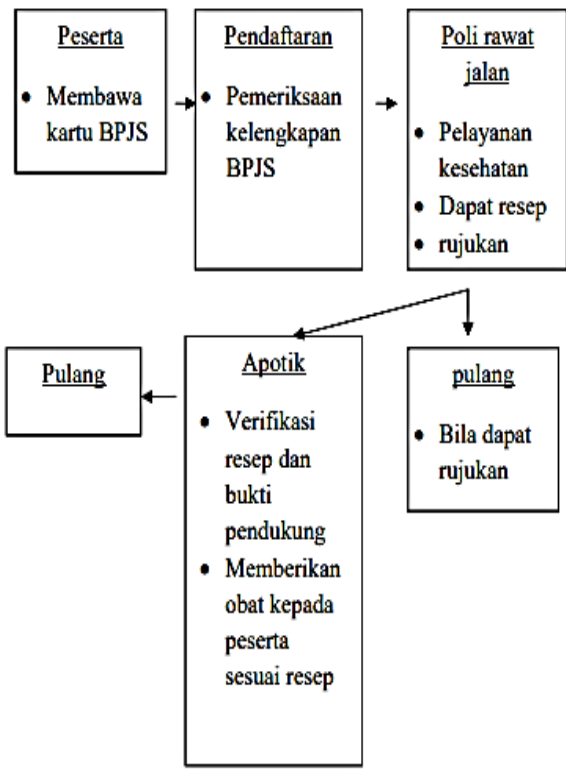

,pasien tanpa rujukan dan pasien dengan tingkat emergency atau kegawatdaruratan.

Gambar 2.2 alur pelayanan rawat inap

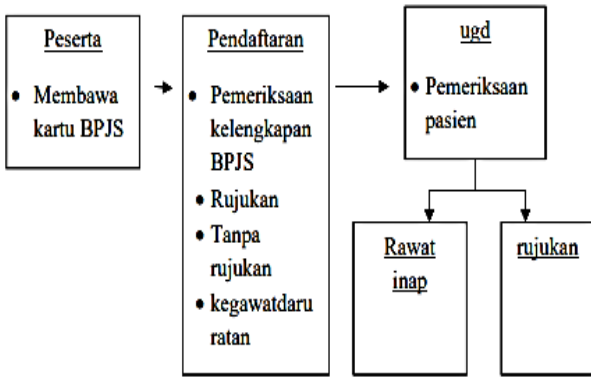

\section{Kendala Didalam Pelaksanaan Jaminan Sosial di Kota Tanjungbalai}

Adapun yang menjadi suatu kendala dalam pelaksanaan suatu jaminan sosial bagi masyarakat kota Tajungbalai dapat dikategorikan ke dalam beberapa bentuk yaitu:

\section{Keterbatasan Ekonomi}

Keterbatasan ekonomi dimana masyarakat kota Tanjungbalai yang berpenghasilan dari nelayan dengan memenuhi kehidupan sehari-hari sudah berkecukupan. Banyak masyarakat yang belum berusia dewasa yang tinggal didaerah pesisir yang mengalami suatu putus sekolah dikarenakan keterbatasan ekonomi yang dimiliki oleh keluarga. Mencari makan sehari-hari saja mereka merasa cukup namun bila dikenakan pembebanan untuk dikenakan suatu tagihan iuran dalam memenuhi suatu kewajiban membayar BPJS kesehatan tentu merasa keberatan. Walaupun kesehatan merupakan suatu kebutuhan primer bagi kehidupan manusia. Namun dengan keterbatasan suatu penghasilan membuat masyarakat untuk melupakan sejenak untuk tertib membayar administrasi kesehatan. Tujuan dari badan penyelenggara kesehatan merupakan tujuan perlindungan kesehatan yang bersifat secara positif namun ini dipandang oleh sebagian kalangan masyarakat merupakan suatu beban.

Penyelenggaraan kesehatan yang dilakukan oleh badan penyelenggara kesehatan mengalami suatu kendala, banyak masyarakat yang tidak secara menyeluruh untuk didapatkan suatu jaminan kesehatan. Karena masyarakat sebagian tersebut teridiri dari masyarakat kebanyakan yang berada dan tinggal yang mencari 
suatu nafkah didaerah pesisir. Hal ini menjadi suatu problema. Perlunya dilakukan suatu penanggulangan bagi setiap lapisan masyarakat daerah pesisir untuk mendapatkan suatu perlindungan dengan jaminan kesehatan. Pemerintah daerah kabupaten Asahan perlu mendiskusikan ini dan segera membuat program kebijakan dalam menumbuhkan ekonomi masyarakat agar kewajiban dalam memenuhi pembayaran iuran BPJS kesehatan dapat terlaksana.

\section{Keterbatasan Pendidikan}

Keterbatasan pendidikan yang dimiliki oleh masyarakat kota Tanjungbalai khususnya yang berada di suatu daerah pesisir memprihatinkan, dimana dengan keterbatasan pendidikan sulit bagi BPJS Kota Tanjungbalai untuk menyelenggarakan jaminan kesehatan. Masyarakat daerah pesisir hampir rata-rata tidak memiliki suatu kelengkapan administrasi kependudukan seperti KTP maupun Kartu Keluarga. Sehingga hal ini dalam melakukan pengurusan BPJS mengalami suatu hambatan karena tidak terpenuhinya kelengkapan administrasi kependudukan.

Masyarakat yang belum lengkap administrasi kependudukannya mengalami suatu kendala. Pihak BPJS kesehatan menyarankan untuk melakukan pelengkapan administrasi data kependudukan. Disisi lain masyarakat mengalami suatu kendala dalam melakukan suatu pengurusan data kependudukan karena kurangya pengetahuan dalam melakukan pengurusan jaminan kesehatan. Masyarakat yang tersangkut dalam pengurusan jaminan kesehatan merasa menyerah untuk tidak melakukan pengurusan BPJS karena keterbatasan kelengkapan data maupun pengetahuan yang dimiliki.

Berdasarkan hal tersebut maka perlu bagi pemerintah daerah untuk melakukan suatu pengkajian untuk memikirkan solusi mengatasi permasalahan-permasalahan yang dihadapi oleh masyarakat. Masyarakat perlu dilakukan pembantuan untuk mendapatkan suatu jaminan kesehatan. Pihak badan penyelenggara kesehatan perlu melakukan suatu ordinasi kepada pemerintah daerah terkait masih banyaknya masyarakat Kota Tanjungbalai yang masih belum mendapatkan suatu jaminan kesehatan. Hingga perlu dilakukan grafik maupun data jumlah masyarakat kota Tanjungbalai dengan jumlah kartu jaminan kesehatan yang dikeluarkan. Pemerintah harus mampu mendorong masyarakat melalui perangkat daerahnya untuk segera melakukan pengurusan suatu jaminan kesehatan.

Bila hal ini dibiarkan maka cita-cita nasional untuk mensejahterakan rakyat akan tidak tercapai. Karena masyarakat yang sejahtera dalam masyarakat yang sehat. Masyarakat yang sehat akan mampu meningkatkan pertumbuhan ekonomi dan mendorong kemajuan suatu roda perekonomian pemerintah daerah maupun pemerintah pusat. Ekonomi yang meningkat akan mencerdaskan kehidupan bangsa dengan konsumsi makanan dan kesehatan yang bergizi bagi masyarakat Kota Tanjungbalai. Hal ini merupakan suatu bagian dari pemberian jaminan kesehatan.

\section{Fasilitas Kesehatan}


Kurangnya fasilitas kesehatan yang ada dirumah sakit umum Kota Tanjungbalai sehingga membuat tidak kondusifnya penanganan suatu pasien dalam mengalami suatu permasalahan kesehatan. Kurangnya ketersedian ruangan kamar opname bagi pasien membuat program jaminan kesehatan tidak terselenggara secara maksimal. Program badan penyelenggara kesehatan bukan hanya diukur dari segi penerbitan ataupun pembayaran iuran BPJS namun implementasi dari program jaminan kesehatan. Jaminan kesehatan itu harus mampu menjamin setiap warga negara Indonesia secara khusus mendapatkan suatu pelayanan kesehatan. Sehingga bila penyelenggaraan pemberian jaminan kesehatan tidak berjalan dengan baik yang tujuannya memberikan suatu penyembuhan atau pemulihan hal ini hanya sebatas semboyan saja.

Pasien yang mengalami ganguan penyakit tentu beraneka macam dengan adanya suatu program BPJS kesehatan maka akan menjangkau setiap lapisan masyarakat untuk mendapatkan suatu perlindungan kesehatan secara prima tanpa terkecuali. Permasalahannya adalah banyak pasien yang dilakukan perujukan pengobatan keluar daerah yang akan memakan waktu yang lama serta membutuhkan suatu biaya dalam perwatannya. Hal ini menjadi suatu permasalahan dalam peranan BPJS dalam memberikan suatu jaminan kesehatan bagi masyarakat Kota Tanjungbalai. Seharusnya pemerintah daerah kota Tanjungbalai harus bersinergi dalam menyelenggarakan suatu program pelayanan kepada masyarakat. Pemerintah daerah kota Tanjungbalai perlu menarukan perhatiannya secara penuh kepada program kesehatan.

\section{Lambatnya Proses Layanan}

Melalui program BPJS tentu perlunya dilakukan suatu pelayanan yang prima cepat dan akurat. Namun kenyataan yang terjadi dilapangan sebagian masyarakat lebih memilih untuk mengunaka jasa konsultasi kesehatan secara pribadi kepada dokter spesialis dengan langsung secara bayaran pakai uang pribadi. Dibandingkan dengan mengunakan kartu BPJS mengalami berbagai proses yang dianggap masyarakat rumit dan berbelit-belit. Hal inilah yang terjadi selalu terjadi dilapangan. Masyarakat merasa kurang mendapatkan suatu manfaat secara penuh dalam adanya program BPJS kesehatan.

Perlunya dilakukannya suatu perbaikan dan koreksi dalam hal ini yang merupakan suatu krusial yang perlu diperhatikan dan diperbaiki. Jangan sampai masyarakat hanya mengangap bahwa program BPJS hanyalah sebatas program kesehatan namun tidak menjangkau suatu kesehatan bagi masyarakat. Serta perlunya publikasi secara jelas dan memudahkan masyarakat untuk memahami program BPJS kesehatan.

Wujud akuntabilitas negara dalam menjamin kesejahteraan rakyatnya. Melalui mekanisme BPJS ini diharapkan keinginan masyarakat Indonesia akan kesehatan dapat terjamin, sehingga banyak kasus pengabaian penderita yang sebelumnya tidak mempunyai uang untuk berobat dapat teratasi dan tidak muncul lagi di masa mendatang.

Sebelum adanya BPSJ masih banyak manusia yang belum mendapatkan sesuatu yang terjamin 
secara adil dan merata. Terlebih non PNS selalu dikecualikan untuk mendapatkan pelayanan kesehatan dibandingkan dengan PNS. Angka hitungan ini menimbulkan masalah di antara lingkungan sekitar yang melibatkan asuransi kesehatan. Waktu berlalu dan pembenahan generasi BPSJ hadir untuk mengatasi segala permasalahan kesehatan. Dengan menawarkan pelayanan kesehatan untuk semua orang selain pengecualian. Pelimpahan tanggung jawab untuk menanggung beban risiko tersebut, kepada berbagai kejadian yang berada dalam posisi untuk mengambil alih tanggung jawab. ${ }^{17}$

BPJS sebagai perlindungan asuransi yang diberikan kepada negara kepada setiap warga negara yang memberikan perlindungan kesehatan kepada negara. Negara ingin memberikan jaminan kesehatan kecuali untuk setiap warga negara kecuali membedakan semua jenis lingkaran publik dan pribadi. Bahkan pihak berwenang berkewajiban memastikan bahwa setiap warga lingkungan dari Sabang hingga Marauke telah mendapatkan layanan kesehatan dan asuransi nasional.

Kota Tanjungbalai mesti memiliki struktur birokrasi yang cepat dan efektif dan kejelasan SOP karena di lapangan masih adanya lempar tanggungjawab didalam penanganan pasien BPJS. Struktur birokrasi ini berupa susunan komponen (unit-unit) kerja didalam organisasi yang menunjukan adanya pembagian kerja serta adanya kejelasan bagaimana fungsi-fungsi atau kegiatan yang

17 Sri Rejeki Hartono, Hukum Asuransi Dan Perusahaan Asuransi. hlm, 12. berbeda-beda diintegrasikan atau dikoordinasikan sesuai dengan standar operasional prosedur (SOP) yang ialah aspek organisasi yang telah ditetapkan. Dari sisi peraturan dan sumberdaya BPJS sebenarnya sudah mencukupi tetapi dari sisi layanan kepada masyarakat masih kurang sehingga ditandai masih tingginya kekecawan masyarakat baik didalam layanan kepesertaan dan didalam perihal layanan kesehatan. Di sisi lain masyarakat tidak berdaya bagi karena ketentuan bahwa masyarakat "wajib" menjadikan anggota BPJS sehingga mau tidak mau mereka mesti mendaftar sebagai anggota/peserta BPJS.

Rendahnya kualitas pelayanan publik merupakan salah satu sorotan yang diarahkan pada bentuk pemerintah dalam menawarkan pelayanan kepada publik. Peningkatan penawaran publik dalam reformasi teknologi adalah harapan semua orang, tetapi tunggangan itu tidak lagi memiliki keterampilan raksasa perubahan. Berbagai respon masyarakat ternyata cenderung menunjukkan bahwa cukup banyak jenis pelayanan publik yang mengalami kemunduran yang antara lain ditandai dengan banyaknya penyimpangan dalam pelayanan publik yang lamban dalam memberikan pelayanan serta merupakan salah satu komponen dari penawaran umum yang ada. disorot secara luas.

Berdasarkan disiplin pelayanan publik, telah dilakukan upaya untuk menetapkan kebutuhan pelayanan publik dalam mewujudkan standar penyelenggara publik yang cepat, murah, dan transparan. Hal ini terkait dengan pelaksanaan struktur 
dan pendekatan pelayanan yang tidak efektif, berbelit-belit, lamban, tidak membalas kepentingan, merupakan rangkaian atribut negatif yang dilimpahkan kepada birokrasi. Hal ini merupakan harga yang buruk dari sebuah penyelenggaraan pelayanan kesehatan. Tentunya hal ini terhitung tidak bisa dibenarkan dengan menggunakan wewenang sedemikian rupa sehingga berkewajiban memastikan bahwa setiap emiten penyedia kesehatan harus dimaksimalkan dalam menyelenggarakan kesehatan.

BPSJ yang menjadi sorotan dalam pembelajaran ini dalam menyelenggarakan beberapa hal perencanaan asuransi kesehatan yang ada di suatu kabupaten / kota. Berhasil tidaknya struktur rencana jaminan kesehatan dan penawaran kesehatan yang diterapkan BPJS bergantung pada standar operasional yang dimiliki dan pelaksanaan penawaran kesehatan yang dapat dilihat oleh masyarakat. Lingkungan adalah penentu dan penentu perlunya beberapa hal penyelenggaraan kesehatan yang dilakukan untuk BPJS. Karena pada prinsipnya BPJS merupakan cakupan dari wewenang pusat dimana setiap tempat harus tetap menjadi wadah yang sederajat berdasarkan kebutuhan operasional di masing-masing kabupaten / kota.

$$
\text { Lembaga Penyelenggara }
$$

Jaminan Sosial untuk penguasa negara dengan bantuan regulasi adalah regulasi jaminan sosial, dimana lembaga BPJS tersebut sekarang tidak terdaftar di notaris dan tidak menginginkan persetujuan dari instansi yang berwenang. Tujuan diselenggarakannya suatu jaminan sosial merupakan suatu cita-cita bangsa untuk mewujudkan kesehatan bagi seluruh rakyat Inonesia. Melalui program jaminan kesehatan akan menumbuhkan masyarakat sehat dan sejahtera. Dengan masyarakat Indonesia sehat dan sejahtera maka akan memberikan mendorong kemajuan bagi suatu negara.

Pemikiran sederhana yang mendasari rumusan SJSN terselenggaranya suatu jaminan kesehatan bagi segenap rakyat Indonesia adalah bahwa terlaksananya suatu jaminan sosial dilandasi sepenuhnya pada setiap orang yang dijamin oleh konstitusi yaitu laki-laki atau perempuan dalam konstitusi pasal $28 \mathrm{~h}$ ayat (3) mengatur, "Setiap orang berhak atas perlindungan sosial yang memungkinkan perkembangan dirinya seutuhnya, sebagai manusia yang bermanfaat. ${ }^{18}$

Terselenggaranya jaminan sosial merupakan salah satu bentuk tugas bangsa dari perbaikan sistem keuangan dan kesejahteraan masyarakat di seluruh negeri. Berdasarkan Konstitusi Pasal 34 ayat (2) mengatur, "Bangsa mengembangkan sistem pengaman sosial bagi seluruh manusia dan memberdayakan manusia yang rentan dan tidak mampu sesuai dengan martabat kemanusiaan".

Pasal 2 UU SJSN mengatur, "SJSN diselenggarakan berdasarkan asas kemanusiaan, asas kemanfaatan, asas keadilan sosial bagi seluruh rakyat Indonesia". Didalam ketentuan jaminan kesehatan bahwa setiap orang dijamin untuk mendapatkan suatu fasilitas kesehatan bagi segenap bangsa Indonesia. Memenuhi

18 Sulastomo, Sistem Jaminan Sosial Nasional, ed. Rajawali Press (Jakarta, 2008). 
keinginan mendasar kehidupan kelas satu bagi setiap peserta dan anggota keluarganya. Pasal 3 UU SJSN menyatakan, "SJSN berupaya untuk menjamin keberhasilan keinginan mendasar dari eksistensi terhormat bagi setiap peserta dan / atau anggota rumah tangga. ${ }^{19 "}$

Badan Penyelenggara Jaminan Sosial yang selanjutnya disingkat BPJS adalah badan hukum yang dibentuk untuk memberlakukan polis jaminan perlindungan sosial (UndangUndang Nomor 24 Tahun 2011). BPJS terdiri dari BPJS Kesehatan dan BPJS Ketenagakerjaan. Hadirnya suatu jaminan sosial di Inonesia maka akan menghapuskan bentuk-bentuk lain dari suatu jaminan yang bersifat kehetan. Program jaminan kesehatan terdahulu dihapuskan yaitu jamsostek serta jamkesmas. Penghapusan tersebut bertujuan untuk mengadopsi jaminan kesehatan yang baru yang di miliki kewenangannya oleh lembaga jaminan kesehatan yaitu BPJS.

Bentuk beraneka ragam dengan mengkategorikan kelas-kelas dalam suatu jaminan kesehatan yaitu bawah, menengah dan atas. Bentuk jaminan ini dapat dipilih oleh setiap masyarakat yang akan mendapatkan suatu jaminan kesehatan oleh negara. Negara akan memberikan suatu fasilitas kesehatan berdasarkan pertanggungan kelas-kelas dalam suatu jaminan kesehatan. Dengan pemberian suatu beban iuran yang harus dipenuhi oleh masyarakat untuk mendapatkan suatu jaminan kesehatan.

Memberlakukan kebijakan keselamatan yang bertujuan untuk

${ }^{19}$ Ibid. memberikan jaminan keselamatan dan kesejahteraan sosial bagi seluruh rakyat Indonesia. Mengingat posisi BPJS yang diperlukan dalam melaksanakan polis jaminan perlindungan sosial yang menutupi seluruh penduduk Indonesia, UU BPJS menawarkan batasan yang jelas mengenai fungsi, tanggung jawab dan kewenangan jaminan kesehatan. Jaminan kesehatan memberikan batasan yang jelas mengenai fungsi, tanggung jawab dan kewenangan BPJS. Dengan demikian dapat diketahui dengan walk in the park batasan-batasan tugasnya dan sekaligus dapat digunakan sebagai kemampuan. Memberikan batasan yang jelas mengenai fungsi, kewajiban dan kewenangan BPJS. Dengan demikian dapat diketahui secara tepat batasan kewajibannya dan sekaligus dapat digunakan sebagai kapabilitas.

\section{KESIMPULAN}

Bagi $\begin{array}{ccc}\text { Pelaksanaan Jaminan } & \text { Sosial } \\ \text { Masyarakat Bagi } & \text { Badan }\end{array}$ Penyelenggaraan Jaminan Sosial (BPJS) di Kota Tanjungbalai. Telah sesuai dengan ketentuan hukum yang berlaku dalam memberikan suatu jaminan kesehatan. Namun perlunya dilakukan suatu peningkatan dalam menyelenggarakan suatu pelayanan publik kepada masyarakat dalam bidang kesehatan. Penyelenggaraan jaminan kesehatan tersebut adalah berdasarkan ketentuan BPJS dilaksanakan pembayara iuran dalam mendapatkan suatu jaminan kesehatan berupa kartu jaminan kesehatan. Kartu jaminan kesehatan tersebut dibagi atas kelas-kelas dalam suatu pelayanan kesehatan. Dengan suatu pengkategorian golongan I,II dan III. 
Penggolongan kategori tersebut merupakan suatu pembeda dalam mendapatkan suatu pelayanan kesehatan karena diukur dari segi nominal iuran yang akan dibayarkan dalam menyelenggarakan suatu jaminan kesehatan. Setiap masyarakat mendapatkan suatu pelayanan secara merata namun ada pembeda yang dilakukan berdasarkan ketentuan aturan BPJS dalam memberikan suatu pelayanan kesehatan bagi masyarakat.

Kendala Didalam Pelaksanaan Jaminan Sosial di Kota Tanjungbalai. Adapun yang menjadi suatu kendala dalam pelaksanaan suatu jaminan sosial bagi masyarakat kota Tajungbalai dapat dikategorikan ke dalam beberapa bentuk yaitu: Keterbatasan Ekonomi Keterbatasan ekonomi dimana masyarakat kota Tanjungbalai yang berpenghasilan dari nelayan dengan memenuhi kehidupan sehari-hari sudah berkecukupan. Banyak masyarakat yang belum berusia dewasa yang tinggal didaerah pesisir yang mengalami suatu putus sekolah dikarenakan keterbatasan ekonomi yang dimiliki oleh keluarga. Keterbatasan Pendidikan Keterbatasan pendidikan yang dimiliki oleh masyarakat kota Tanjungbalai khususnya yang berada di suatu daerah pesisir memprihatinkan, dimana dengan keterbatasan pendidikan sulit bagi BPJS Kota Tanjungbalai untuk menyelenggarakan jaminan kesehatan. Fasilitas Kesehatan Kurangnya fasilitas kesehatan yang ada dirumah sakit umum Kota Tanjungbalai sehingga membuat tidak kondusifnya penanganan suatu pasien dalam mengalami suatu permasalahan kesehatan. Kurangnya ketersedian ruangan kamar opname bagi pasien membuat program jaminan kesehatan tidak terselenggara secara maksimal.

Perlunya peningkatan layanan dengan memberikan sesuatu petunjuk kepada masyarakat didalam mengiakan kebijakan pemerintah yang berkaitan dengan BPJS Kesehatan. Perlunya peningkatan koordinasi dengan pihak kesehatan lainnya didalam perihal sesuatu permasalahan yang terjadi ketika masyarakat mengalami kendala dan masalah kesehatan serta berkaitan dengan kebijakan BPJS.

\section{DAFTAR PUSTAKA}

\section{Buku}

2017, Seminar Nasional

Multidisiplin Ilmu, and

Junindra Martua. "Peran

Birokrasi Pemerintah

Sebagai Penyelenggara

Pelayanan Publik," 2017.

https://doi.org/10.31227/osf.i

o/5xvew.

Ade Irma Suryani, Agung Suharyanto. "Implementasi

Kebijakan Badan

Penyelenggara Jaminan

Kesehatan (BPJS) Didalam

Meningkatkan Layanan

Administrasi Kesehatan Di

Rumah Sakit Umum

Silabuhuan Kabupaten

Padang Lawas,." Jurnal

Administrasi Publik, n.d.

Indra Perdana, Mangaraja

Manurung. "Tinjauan

Yuridis Tentang

Perlindungan Pekerja Migran

Ditinjau Dari UU No. 17

Tahun $2017 \quad$ Tentang

Perlindungan Pekerja Migran

Indonesia." Jurnal Pionir

Vol 6, No (2020): 1-7. 
Pasal 1 Angka 1, Peraturan

Pemerintah Republik

Indonesia Nomor 101 Tahun

2012, Tentang Penerima

Bantuan Dana Jaminan

Kesehatan., n.d.

Rini Liana, Emmi Rahmiwita, Zaid Afif. "Jurnal Pionir LPPM Universitas Asahan Vol. 5 N0.4 Juli-Desember 2019" 5, no. 24 (2019): 34348.

Sri Rejeki Hartono. Hukum Asuransi Dan Perusahaan Asuransi. Edited by Sinar Grafika. Jakarta, 2008.

Sulastomo. Sistem Jaminan Sosial Nasional. Edited by Rajawali Press. Jakarta, 2008.

Wawancara Dengan Bidang SDM, Umum Dan Komunikasi, Mohamad Syafriadi Didampingi Dessy Prassinta Selaku Kepala Bidang Penjaminan Manfaat Rujukan, Dan Dewi Irmayani Harahap Selaku Kepala Bidang Penjaminan Manfaat Primer., n.d.

\section{Peraturan Perundang-undangan}

Peraturan Pemerintah Republik Indonesia Nomor 101 Tahun 2012, tentang Penerima Bantuan Dana Jaminan Kesehatan. 